\title{
Source Apportionment and Macro Tracer: Integration of Independent Methods for Quantification of Woody Biomass Burning Contribution to $\mathbf{P M}_{10}$
}

\author{
Milena Stracquadanio, Ettore Petralia ", Massimo Berico, Teresa M.G. La Torretta, \\ Antonella Malaguti, Mihaela Mircea, Maurizio Gualtieri, Luisella Ciancarella \\ Laboratory of Atmospheric Pollution, National Agency for New Technologies, Energy and Sustainable Economic \\ Development, ENEA, 40129 Bologna, Italy
}

\begin{abstract}
During the last few years, the rise in woody biomass burning (BB) for household heating has caused an increase in PM mass concentrations, particularly for the fine fraction, in Europe, as reported by the European Environmental Agency. Estimating the contribution from biomass combustion to airborne particulate matter is therefore an important issue in air quality governance, due to its potential health and environmental impacts.

Wood burning's contribution to $\mathrm{PM}_{10}$ was estimated in winter at a rural site in southern Italy by means of two independent methods: source apportionment analysis with Positive Matrix Factorization $\left(\mathrm{BB}_{\mathrm{PMF}}\right)$ and the macro tracer approach, based on levoglucosan concentrations $\left(\mathrm{BB}_{\mathrm{Levo}}\right) . \mathrm{PM}_{10}$ and $\mathrm{PM}_{2.5}$ samples were collected every $24 \mathrm{~h}$ and every $8 \mathrm{~h}$, respectively, and analyzed to determine the organic and elemental carbon, levoglucosan, inorganic ions and elements.

The results obtained via these methods showed good agreement $(r=0.85)$, with a linear correlation slope of about 1 , and provide a reliable assessment of the BB contribution.

Woody biomass combustion contributed significantly to the $\mathrm{PM}_{10}$ (on average, slightly less than $30 \%$ of the total mass) during winter. The combination of the independent methods proposed here may be used as a methodology for refining the $\mathrm{BB}$ contribution to air pollution.
\end{abstract}

Keywords: Biomass combustion; Particulate matter; Levoglucosan; PMF; Emission sources.

\section{INTRODUCTION}

National and international environmental policies point out the need for identifying and quantifying the contribution of emission sources to atmospheric concentrations, distinguishing also the contribution of the local and regional sources from the long-range transported pollutants. Air Quality Directives (Council Directive 2008/50/EC; Council Directive 2004/107/EC) reinforce the importance of having information on pollution sources for the development of efficient air quality plans and for the evaluation of human risk-exposure.

Identification and quantification of the air pollution sources have been performed with various methodologies such as explorative methods, emission inventories, photochemical and dispersion models (Lagrangian, Gaussian and Eulerian models) and receptor models (Viana et al., 2008; Belis et al., 2014). The receptor models (RMs, e.g., Principal Component

\footnotetext{
* Corresponding author.

Tel.: + 390516098558

E-mail address: ettore.petralia@enea.it
}

Analysis, Multilinear Engine, Chemical Mass Balance) are mathematical or statistical procedures that are able to provide information on the contribution of emitting sources at a specific receptor site using in-situ measured experimental data and solving a mass balance equation, some of which may run also without the knowledge of the pollution sources.

One of the most commonly RMs used is the Positive Matrix Factorization (PMF, P. Paatero, Helsinki, Finland; Paatero and Tapper, 1994) that explains the correlation between the different measured species (carbonaceous fractions, inorganic ions, trace metals, etc.) through their linear combinations. These combinations, resulting in clustered "factors" (sources), originate from hidden common trends of species.

In the last years the international research community, e.g., European Commission with the Forum for Air quality Modelling (FAIRMODE; http://fairmode.jrc.ec.europa.eu/) and United States Environmental Protection Agency (https://www.epa.gov/scram/air-pollutant-receptor-modeling) have dealt with source apportionment matter and some basic guidelines and procedures (Belis et al., 2014; Norris et al., 2014; Pernigotti et al., 2016) are in continuous improvement for joint assessment protocols among all the 
scientific subject involved in air quality evaluation (Karagulian et al., 2012; Belis et al., 2015a, b).

Source apportionment is gaining relevance in highly polluted areas to identify the main emission sources affecting air quality in order to propose/develop/implement protocols and strategies aiming at the reduction of air pollution.

Among the most relevant anthropogenic emission sources (such as vehicular traffic, industrial and agriculture activities), an important contribution is given by biomassbased household heating appliances during wintertime. In the last years, woody biomass burning (BB) for domestic or residential heating has increased its diffusion driven by climate and energy policy and the higher costs of other fuels (EC Commission Stuff Working Document, 2014; EC Renewable Energy Progress Report, 2015).

The incomplete or inefficient combustion of wood biomass in conditions typical of small and medium domestic heating device use has been recognized as an important source of particulate matter $\left(\mathrm{PM}_{10}, \mathrm{PM}_{2.5}, \mathrm{PM}_{1}\right)$ and other air pollutants harmful to human health (EC Commission Staff Working Document, 2014; WHO, 2015, www.eea.europa.eu/ publications/air-quality-in-europe-2015/download).

Quantification of BB contribution is still challenging due to mixing of sources, heating device type, species of wood and combustion conditions, and meteorology. BB contribution to PM is usually estimated by using RMs (Bernardoni et al., 2011; Waked et al., 2014; Petralia et al., 2017) or specific macro tracer approaches (Sdizat et al., 2006; Schmidl, 2008; Piazzalunga et al., 2011; Shahid et al., 2019).

The macro tracer approach is based on the identification of markers (such as levoglucosan or ${ }^{14} \mathrm{C}$ ) that are directly related to biomass combustion emissions allowing thus the estimation of $\mathrm{BB}$ contribution to the mass concentration of PM. Levoglucosan and its stereoisomers, mannosan and galactosan, are monosaccharide anhydrides produced by pyrolysis processes at temperatures higher than $300^{\circ} \mathrm{C}$ of cellulose and hemicellulose, respectively, and are considered specific markers of BB (Simoneit et al., 1999; Fine et al., 2002; Gelencsér et al., 2007; Yttri et al., 2011; Nielsen et al., 2017). Levoglucosan may undergo degradation processes in the atmosphere due to oxidation reactions with radicals present in the ambient air; in particular, the reactions with the $\mathrm{OH}$ radical have been widely studied (Hennigan et al., 2010; Hoffman et al., 2010; Lai et al., 2014). In fact, levoglucosan atmospheric lifetime could vary widely between 1.2 and 3.9 days (Lai et al., 2014) under different environmental condition (temperature [T] and relative humidity $[\mathrm{RH}]$ ), $\mathrm{OH}$ concentration, other atmospheric radical concentrations and levoglucosan mixing state together with inorganic salt and soot (Hennigan et al., 2010; Hoffman et al., 2010; Lai et al., 2014). As a consequence, the use of levoglucosan for estimating the contribution of $\mathrm{BB}$ to $\mathrm{PM}$ is under debate since the possible underestimation due to the marker degradation, particularly in summer atmospheric conditions and/or sampling aged PM (Busby et al., 2016). The macro tracer approach proposed by Schmidl et al. (2008) estimates the $\mathrm{BB}$ contribution to $\mathrm{PM}_{10}$ depending on the levoglucosan atmospheric concentration through a specific conversion factor related to the wood species burnt and BB fuel type (logs or pellets). This method, already applied in Italy (Piazzalunga et al., 2011), results in more precise site specific conversion factor assessment and so for BB contribution estimation, since it considers the species and fuel type actually burnt at certain area.

Despite the wide application of these methods, both show advantages and limits. PMF allows to obtain information on the contribution of emission sources in a specific receptor site without knowing a priori the different types of sources persisting at a site; on the contrary, the contribution, in terms of absolute concentration value, could be underestimated. Indeed, the analytical speciation of the chemical composition of PM is never complete, because of the difficulties in determining the water content, in establishing a complete and specific geochemical characterization of various metal oxide, and in assessing the best organic matter (OM) quantification (Sciare et al., 2005; Bae et al., 2006; Terzi et al., 2010; Perrino et al., 2013; Perrino et al., 2014; Genga et al., 2017). The lack of this information affects considerably $\mathrm{PM}_{10}$ mass reconstruction from the characterized species (Belis et al., 2014). Macro tracer approach allows to estimate the $\mathrm{BB}$ contribution to PM from a single tracer (levoglucosan) but this evaluation is highly dependent on the knowledge of local type of solid biomass fuel (logs, chips, pellets, bark and sawdust) and wood species consumption inventory as well as on levoglucosan degradation processes; both factors lead to the uncertainty or underestimation of the real BB contribution.

This study estimates the $\mathrm{BB}$ contribution to $\mathrm{PM}_{10}$ samples collected at a rural site located in the south of Italy during winter by applying PMF and macro tracer methods in an independent and complementary way. The simultaneous application of these methods may improve our possibility to correctly evaluate the $\mathrm{BB}$ contribution to air pollution leading to a more accurate and "realistic" quantification and to obtain more reliable site specific BB evaluation.

\section{MATERIALS AND METHODS}

\section{PM Sampling and Measurement Techniques}

The aerosol was sampled in a coastal zone in Apulia (Italy) (Fig. 1(a)) at three sites: Cisternino $\left(40.74278^{\circ} \mathrm{N}\right.$; $\left.17.41583^{\circ} \mathrm{E}\right), \quad$ Torchiarolo-Lendinuso $\quad\left(40.5175^{\circ} \mathrm{N}\right.$; $\left.18.07889^{\circ} \mathrm{E}\right)$ and Torchiarolo-Fanin $\left(40.48945^{\circ} \mathrm{N}\right.$; $\left.18.04723^{\circ} \mathrm{E}\right)$. Cisternino (Ci) site is defined as rural site, while Torchiarolo-Lendinuso (TL) and Torchiarolo-Fanin (TF) are classified as suburban sites (according to the criteria in Italian Decr. Leg. 13 agosto 2010, n. 155). Ci is located $11 \mathrm{~km}$ from the sea and at an elevation of $400 \mathrm{~m}$, TL and TF are located 0.7 and $5 \mathrm{~km}$ away from the sea respectively at an elevation of $30 \mathrm{~m}$ a.s.l. The area around the urban sites is moderately urbanized but highly agricultural, characterized by olive groves, vineyards, nonirrigated arable areas and complex crops. All these landcover typologies determine soils exposure by the wind erosion with eventual re-suspension phenomena of soil and dust material. The distances of Torchiarolo from larger cities 


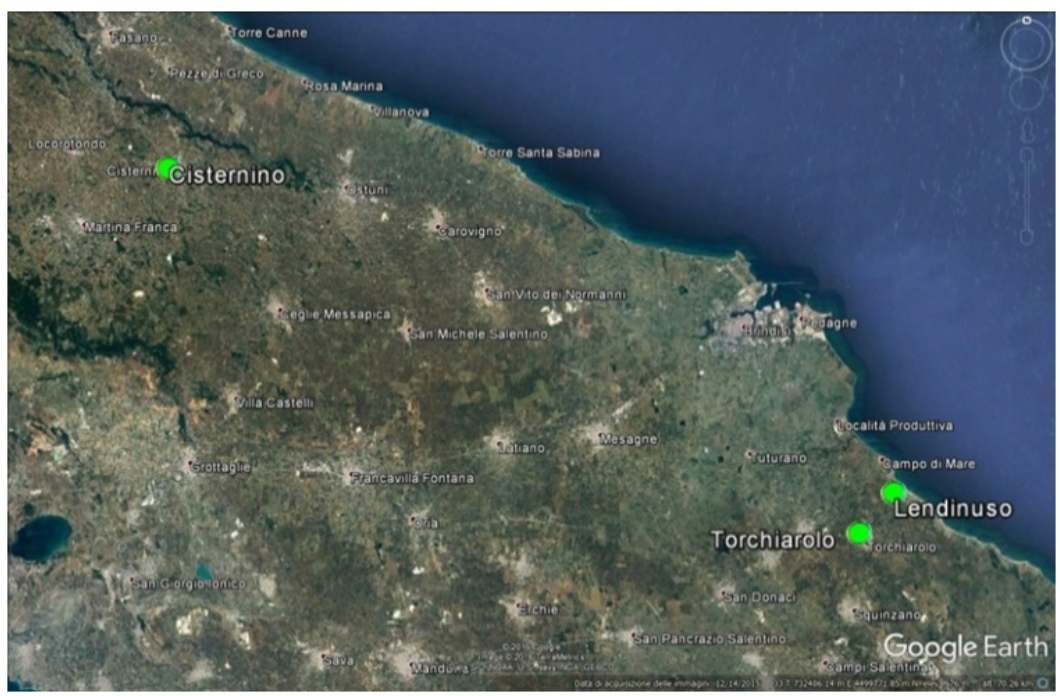

(a)

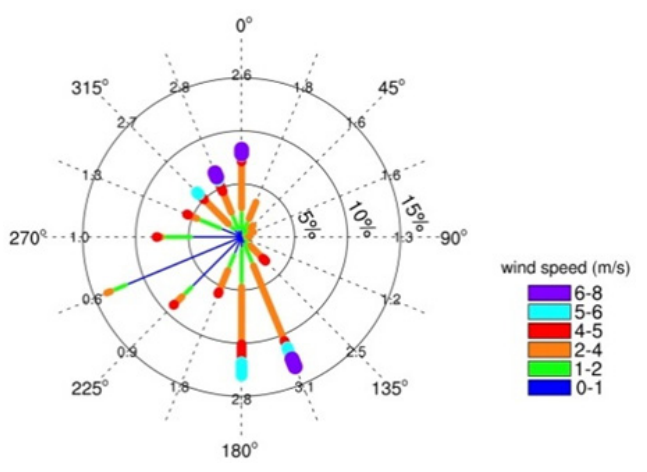

(b)

Fig. 1. Sampling sites: (a) Torchiarolo (Torchiarolo-Fanin [TF]), Cisternino (Cisternino [Ci]), Lendinuso (TorchiaroloLendinuso [TL]) (elab. from https://www.google.com/earth/). (b) Wind rose.

in the region are $16 \mathrm{~km} \mathrm{NNW}$ and $16 \mathrm{~km}$ SSE for Brindisi and Lecce respectively, while Taranto is located $65 \mathrm{~km}$ WSW. The nearest medium size towns are San Pietro Vernotico $(4 \mathrm{~km} \mathrm{~W})$ and Squinzano $(5 \mathrm{~km} \mathrm{~S})$. The four lane motorway Strada Statale 613 is located around 600 meters W-SW. The prevalent directions of wind during the sampling period were WSW and S-SSE and the wind velocities vary from weak (up to $2-4 \mathrm{~m} \mathrm{~s}^{-1}$ ) to moderate (up to 6-8 $\mathrm{m} \mathrm{s}^{-1}$ ) (Fig. 1(b)).

$\mathrm{PM}_{10}$ was sampled in all three sites with FAI Hydra Dual Sampler. At TF, the measurements were carried out with the following instruments: Sunset Laboratory Model-4 Semi-Continuous OCEC Field Analyzer, Aerodyne Aerosol Chemical Speciation Monitor (ACSM), FAI Hydra Dual Sampler (equipped with $\mathrm{PM}_{2.5}$ sampling head) and VAISALA MAWS 100 weather station.

24-hour $\mathrm{PM}_{10}$ samples were collected on polytetrafluoroethylene (PTFE) membranes and quartz fiber filters for 30 consecutive days, from 23 January to 21 February 2016; 29 parameters were quantified: organic carbon (OC), elemental carbon (EC), inorganic ions $\left(\mathrm{Cl}^{-}\right.$, $\left.\mathrm{NO}_{3}^{-}, \mathrm{SO}_{4}{ }^{2-}, \mathrm{Na}^{+}, \mathrm{NH}_{4}^{+}, \mathrm{K}^{+}, \mathrm{Mg}^{2+}, \mathrm{Ca}^{2+}\right)$, elements ( $\mathrm{Al}, \mathrm{Si}$, $\mathrm{Ti}, \mathrm{V}, \mathrm{Cr}, \mathrm{Mn}, \mathrm{Fe}, \mathrm{Co}, \mathrm{Ni}, \mathrm{Cu}, \mathrm{Zn}, \mathrm{As}, \mathrm{Ba}, \mathrm{W}, \mathrm{Pb}, \mathrm{Sc}, \mathrm{Ce}$, $\mathrm{Rb}$ ) and gravimetric $\mathrm{PM}_{10}$. The chemical characterization of $\mathrm{PM}_{10}$ was used as input for PMF (PMF 5.0, USEPA) to identify the emission sources. Only at TF was possible to investigate the macro tracer contribution of biomass combustion using a set of additional parameters such as mass concentration of levoglucosan, $\mathrm{PM}_{2.5}$ with 8-h time resolution and on-line $\mathrm{EC}$ and $\mathrm{OC}$ with 2-h time resolution.

ACSM on-line measurements were conducted from 21 January to 23 February 2016, with 30-min time-resolution. Data were then pooled and mediated over $8 \mathrm{~h}$ or $24 \mathrm{~h}$ in post processing operations, to make species time series data homogeneous in order to perform right comparisons and correlations. ACSM measures the major non-refractory (at $600^{\circ} \mathrm{C}$ ) components of $\mathrm{PM}_{1}\left(\mathrm{NR}-\mathrm{PM}_{1}\right)$ such as Organic
Matter (OM), nitrate $\left(\mathrm{NO}_{3}^{-}\right)$, sulfate $\left(\mathrm{SO}_{4}{ }^{2-}\right)$, ammonium $\left(\mathrm{NH}_{4}{ }^{+}\right)$, chloride $\left(\mathrm{Cl}^{-}\right)$, providing loadings for 100 different macro-molecules (individuated by their mass-to-charge, $\mathrm{m} / \mathrm{z}$ ): In particular, the $\mathrm{m} / \mathrm{z} 60$ is associated to levoglucosan (Alfarra et al., 2007) and so used for comparison with the laboratory levoglucosan measurements.

Gravimetric determination of $\mathrm{PM}_{10}$ and $\mathrm{PM}_{2.5}$ was carried out according to UNI EN 12341 and UNI EN 14907 methods. PM gravimetric mass was determined using an electronic balance $(0.01 \mathrm{mg}$ resolution; model AX205, Mettler Toledo).

Water soluble inorganic ions concentrations $\left(\mathrm{Cl}^{-}, \mathrm{NO}_{3}^{-}\right.$, $\left.\mathrm{SO}_{4}^{2-}, \mathrm{Na}^{+}, \mathrm{K}^{+}, \mathrm{NH}_{4}^{+}, \mathrm{Ca}^{2+}, \mathrm{Mg}^{2+}\right)$ in $24-\mathrm{h} \mathrm{PM}_{10}$ samples were determined according to CEN/TR16269 method. Teflon filters were extracted in 18-M $\Omega$ Milli- $\mathrm{Q}^{\circledR}$ water in ultrasonic bath (32 $\mathrm{min})$ and analyzed by ion chromatography (IC). The detail of the analytical procedure can be found in Malaguti et al. (2015a).

EC and OC mass concentrations were determined in 24-h $\mathrm{PM}_{10}$ samples by means of a Thermal/Optical Carbon Analyzer (Sunset Laboratory Inc.) according to CEN/TR16243:2011 method. On-line EC-OC mass concentrations were measured with Semi-Continuous OCEC Field Analyzer (Model-4, Sunset Laboratory Inc.) every $2 \mathrm{~h}$. The NIOSH-like (RT-QUARTZ-840) thermal optical transmittance protocol was used both for off-line and online analysis. Detailed information about the analytical procedures are reported in Malaguti et al. (2015b).

Metals and trace elements $(\mathrm{Na}, \mathrm{Mg}, \mathrm{S}, \mathrm{Al}, \mathrm{Si}, \mathrm{K}, \mathrm{Ca}, \mathrm{Ti}, \mathrm{V}$, $\mathrm{Cr}, \mathrm{Mn}, \mathrm{Fe}, \mathrm{Co}, \mathrm{Ni}, \mathrm{Cu}, \mathrm{Zn}, \mathrm{As}, \mathrm{Ba}, \mathrm{W}, \mathrm{Pb}, \mathrm{Sb}, \mathrm{Sc}, \mathrm{Ce}, \mathrm{Rb}$ ) were estimated using energy-dispersive $\mathrm{X}$-ray fluorescence (ED-XRF; NEX CG, Rigaku). The calibration was carried out by means of Standard Reference Material ${ }^{\circledR}$ NIST 2783 Air Particulate on Filter Media. The Method Detection Limit (MDL) and combined relative standard uncertainty are reported in Supplementary Material (Table S1).

Anhydrosugars (levoglucosan, mannosan and galactosan) 
were analyzed using High-Performance Anion Exchange Chromatography (HPAEC; Dionex ${ }^{\mathrm{TM}}$ ICS-5000, Thermo Scientific $\left.^{\mathrm{TM}}\right)$ equipped with Thermo Scientific ${ }^{\mathrm{TM}}$ Dionex $^{\mathrm{TM}}$ CarboPac ${ }^{\mathrm{TM}}$ MA1 Analytical $(4 \times 250 \mathrm{~mm}) \&$ Guard $(4 \times$ $50 \mathrm{~mm}$ ) Columns and Pulsed Amperometric Detection (PAD; Dionex $^{\mathrm{TM}}$ ED50A Stand-Alone Electrochemical Detector \& Electrochemical Detector Conductivity Cells, Thermo Scientific $\left.{ }^{\mathrm{TM}}\right)$. Four squares $\left(1 \mathrm{~cm}^{2}\right.$ each) portions of quartz fiber filter from $8 \mathrm{~h}$ PM2.5 samples were extracted with $2 \mathrm{~mL}$ of $18-\mathrm{M} \Omega$ Milli-Q ${ }^{\circledR}$ water in ultrasonic bath $(32 \mathrm{~min})$. Extracted water was filtered to remove debris with a $0.22 \mu \mathrm{m}$ pore size nylon syringe filter $\left(0.2 \mu \mathrm{m}\right.$, Acrodisc ${ }^{\circledR}$ Nylon membrane, Pall ${ }^{\circledR}$ ).

A good resolution between anhydrosugars (levoglucosan, mannosan and galactosan) and sugar alcohols (Arabitol, Sorbitol) was achieved (Fig. 2) developing an analytical method starting from Iinuma et al. (2009) consisting of a gradient elution of a $1 \mathrm{M}$ aqueous sodium hydroxide $(\mathrm{NaOH})$ solution at a flow rate of $0.4 \mathrm{~mL} \mathrm{~min}^{-1}$. Method Detection Limit (MDL) for levoglucosan was evaluated equal to $9.2 \mathrm{ng} \mathrm{m}^{-3}$ by EPA method $\left(M D L=t_{(n-1,1-\alpha=0.99)} \times S D\right.$ where $S D S D$ is the standard deviation of eight replicate standard solution), while the combined relative standard uncertainty $\left(\varepsilon_{\mathrm{R}}\right)$ was 0.07 .

\section{Biomass Burning Identification Methods: Positive Matrix Factorization (PMF) and Macro Tracer Approaches $P M F$}

PMF (USEPA PMF 5.0, Norris et al., 2014; PMF2, Paatero, 2004) was applied to chemical data obtained from $\mathrm{PM}_{10}$ samples collected at the three sites investigated.

PMF performs the decomposition of the measured concentrations dataset ( $X$ matrix) into three different matrices containing the sources, following the mass balance formula:

$X=G \cdot F+E$,

where $G$ is the sources' contribution (time variations) matrix, $F$ is the sources' profiles (such as fingerprint) matrix, and $E$ is the residual (mass not explained by the model) matrix.

PMF can be run on a number of cases (each sampling occasion) which must be minimum three times the number of variables (in our study, 19 different parameters/species) (Belis et al., 2014). The PMF was applied to a dataset $(\mathrm{n}=$ 1767) of 19 measured parameters in 93 daily samples collected at TF, $\mathrm{Ci}$ and TL.

The selected data followed the quality criteria defined by Belis et al. (2014) and Norris et al. (2014) for each parameter: Only measurements parameters having both 50\% of values above detection limit (ADL) and a signal-tonoise ratio $(\mathrm{S} / \mathrm{N})$ value $>1$ were considered. The parameters so used for source profile identification with PMF analysis were $\mathrm{EC}, \mathrm{OC}, \mathrm{Cl}^{-}, \mathrm{NO}_{3}{ }^{-}, \mathrm{SO}_{4}{ }^{2-}, \mathrm{Na}^{+}, \mathrm{NH}_{4}^{+}, \mathrm{K}^{+}, \mathrm{Mg}^{2+}$, $\mathrm{Ca}^{2+}, \mathrm{Al}, \mathrm{Si}, \mathrm{Ti}, \mathrm{V}, \mathrm{Mn}, \mathrm{Fe}, \mathrm{Ni}, \mathrm{Cu}, \mathrm{Zn}$, all considered as "strong" according to Norris et al. (2014); total-gravimetric $\mathrm{PM}_{10}$ was considered as total variable and set as "default to weak" (Norris et al., 2014). This assumption distributed the PM mass among the different sources leading to an almost realistic estimation of $\mathrm{PM}_{10}$ sources. The retrieval of the entire $\mathrm{PM}_{10}$ mass is particularly required for calculation of biomass combustion factor as explained in Section "Estimations of $\mathrm{BB}$ Contribution to $\mathrm{PM}_{10}$-Comparison between Macro Tracer Method and PMF Method". Levoglucosan filter concentrations were not included in the PMF input dataset in order to avoid its eventual influence on source profile definitions and on BB factor calculation. The "Results" section ("Estimations of BB Contribution to $\mathrm{PM}_{10}$-PMF and Source Apportionment") shows two reconstructed $\mathrm{PM}_{10}$ mass: The sum of the masses of all the speciated elements reconstructed by PMF ( $\Sigma$ spec) and as the sole component $\mathrm{PM}_{10}$ reconstructed mass coming from PMF output $\left(\mathrm{PM}_{10}\right.$ comp $)$.

For identification and confirmation, the resulting factors profiles were compared to emissive profiles in SPECIEUROPE database (Pernigotti et al., 2016) and other literature reference-profiles (cit. lit. in Section "Estimations of BB Contribution to $\mathrm{PM}_{10}-\mathrm{PMF}$ and Source Apportionment").

\section{Macro Tracer Method}

$\mathrm{BB}$ contribution to $\mathrm{PM}$ was estimated by macro tracer method proposed by Schmidl et al. (2008) on the basis of

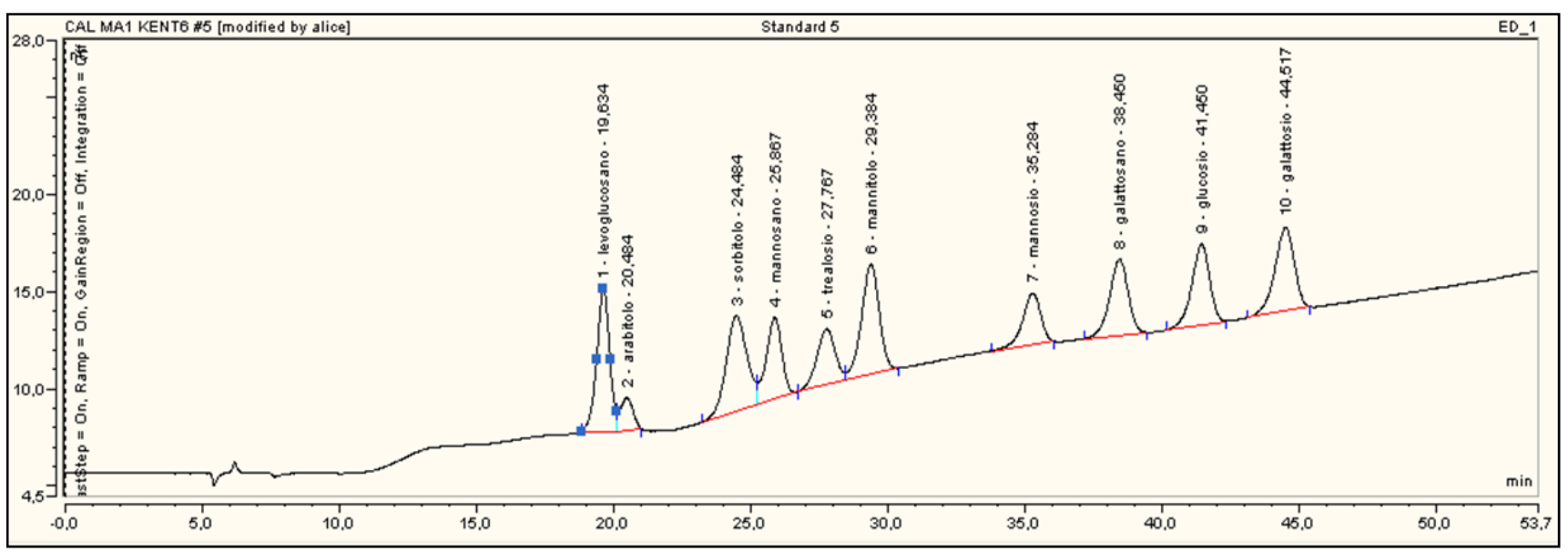

Fig. 2. Anhydrosugars HPAEC-PAD chromatogram. 
wood species and woody fuel type (firewood, pellets or $\operatorname{logs})$.

According to this approach, $\mathrm{PM}_{10}$ mass contribution from biomass burning can be calculated from levoglucosan concentration $\left(B B_{\text {Levo }}\right)$ as follows:

$$
B B_{\text {Levo }}\left(\mu \mathrm{g} \mathrm{m}^{-3}\right)=F_{W n(1 ; 2 ; 3)} \times[\text { Levoglucosan }]\left(\mu \mathrm{g} \mathrm{m}^{-3}\right)
$$

where $F_{W}$ is a conversion factor calculated considering both the woody species burnt in the area of study and the relative spread of pellet burning appliances:

$$
\begin{aligned}
& \mathrm{F}_{\mathrm{W}}=100 /\{\mathrm{c} \text { Beech } \times 4.1+\mathrm{c} \mathrm{Oak} \times 13.3+\mathrm{c} \text { Spruce } \times 10.7 \\
& +\mathrm{c} \text { Larix } \times 15.1+\mathrm{c} \text { Pellet } \times 10.1\}
\end{aligned}
$$

where $c_{i}$ is the weight of each woody species and woody fuel type in the examined site.

This formula takes into account endemic woody species for Austrian and alpine regions where this approach has been developed and applied (Schmidl et al., 2008; Piazzalunga et $a l ., 2011)$. The woody species mainly burned in Apulia are about $70 \%$ olive, approximately $10 \%$ beech and oak, $10 \%$ other local species (e.g., almond tree) according to Spagnolo et al. (2014) and the remaining $10 \%$ is associated to pellet combustion.

The emission factors for olive and for the other endemic species burnt in the study area were not available; therefore, three different hypotheses were considered in the formula proposed by Schmidl. Olive woody biomass emission factor was assumed to be the equal to that reported for oak wood combustion (1) (as in equation $F_{W l}$ ), beech wood combustion (2) $\left(F_{W 2}\right)$ and a combination of $50 \%$ oak and $50 \%$ beech (3) (in $F_{W 3}$ ). Oak and beech were selected as representative of the upper and lower limit of hardwood species $\mathrm{PM}_{10}$ emission factors (Kistler et al.,
2012):

$F_{W 1}=100\{\{0.05$ Beech $\times 4.1+0.85$ Oak $\times 13.3+0.1$ Pellet $\times 10.1\}=8$

$F_{W 2}=100 /(\{0.85$ Beech $\times 4.1+0.05$ Oak $\times 13.3+0.1$ Pellet $\times 10.1\}=19$

$F_{W 3}=100\{0.45$ Beech $\times 4.1+0.45$ Oak $\times 13.3+0.1$ Pellet $\times 10.1\}=11$

\section{RESULTS AND DISCUSSION}

\section{Samples Characterization}

Table 1 shows the mean, median, standard deviation, minimum and maximum values, $25^{\text {th }}$ and $75^{\text {th }}$ percentile concentrations calculated for 24-h samples at TF site for $\mathrm{PM}_{10}, \mathrm{PM}_{2.5}, \mathrm{OC}, \mathrm{EC}$ and levoglucosan. Descriptive statistics for $\mathrm{EC}, \mathrm{OC}, \mathrm{Cl}^{-}, \mathrm{NO}_{3}{ }^{-}, \mathrm{SO}_{4}{ }^{2-}, \mathrm{Na}^{+}, \mathrm{NH}_{4}^{+}, \mathrm{K}^{+}, \mathrm{Mg}^{2+}, \mathrm{Ca}^{2+}$, $\mathrm{Al}, \mathrm{Si}, \mathrm{Ti}, \mathrm{V}, \mathrm{Mn}, \mathrm{Fe}, \mathrm{Ni}, \mathrm{Cu}, \mathrm{Zn}$ of samples from the three examined sites are reported in Supplementary Materials (Table S2).

$\mathrm{PM}_{10}$ shows a mean concentration value of $32 \mu \mathrm{g} \mathrm{m}{ }^{-3}$ with a minimum value of $17 \mu \mathrm{g} \mathrm{m}^{-3}$ and a maximum value $58 \mu \mathrm{g} \mathrm{m}^{-3}$. Daily $\mathrm{PM}_{10}$ limit value of $50 \mu \mathrm{g} \mathrm{m}^{-3}$ set by AQ Directive 50/2008 was exceeded four times during the sampling campaign, on 28 January and 2, 15 and 16 February with $56 \mu \mathrm{g} \mathrm{m}^{-3}, 54 \mu \mathrm{g} \mathrm{m}^{-3}, 58 \mu \mathrm{g} \mathrm{m}^{-3}$ and $52 \mu \mathrm{g} \mathrm{m}^{-3}$, respectively. On the 15 and the 16 of February a Saharan dust intrusion event occurred (Fig. S1), based on $\mathrm{Al}$ concentration value $>1.0 \mu \mathrm{g} \mathrm{m}^{-3}$ and $\mathrm{Ca} / \mathrm{Al}$ ratio $<2$ (according to Koçak et al. (2012)).

Daily $\mathrm{PM}_{2.5}$ concentrations reached the highest values on 28 January with $52 \mu \mathrm{g} \mathrm{m}^{-3}$, almost equal to $\mathrm{PM}_{10}$ and the mean value over the sampling campaign was ca. $22 \mu \mathrm{g} \mathrm{m}^{-3}$. During the campaign, the fine fraction represented on average about $70 \%$ of $\mathrm{PM}_{10}$ daily concentrations.

\begin{tabular}{|c|c|c|c|c|c|c|c|}
\hline & & $\mathrm{PM}_{10}$ & $\mathrm{PM}_{2.5}$ & $\mathrm{PM}_{2.5} / \mathrm{PM}_{10}$ & $\mathrm{EC}$ & $\mathrm{OC}$ & Levoglucosan \\
\hline & & $\mu \mathrm{g} \mathrm{m}^{-3}$ & $\mu \mathrm{g} \mathrm{m}^{-3}$ & $\%$ & $\mu \mathrm{gC} \mathrm{m}^{-3}$ & $\mu \mathrm{gC} \mathrm{m}^{-3}$ & $\mu \mathrm{g} \mathrm{m}^{-3}$ \\
\hline \multirow{9}{*}{$24 \mathrm{~h}$} & Mean & 32 & 22 & 67 & 1.1 & 8.3 & 0.71 \\
\hline & Median & 28 & 16 & 68 & 0.79 & 6.3 & 0.55 \\
\hline & SD & 13 & 13 & 21 & 0.75 & 5.3 & 0.46 \\
\hline & $25^{\text {th }}$ Percentile & 21 & 13 & 52 & 0.49 & 4.5 & 0.41 \\
\hline & $75^{\text {th }}$ Percentile & 45 & 25 & 82 & 1.8 & 11.5 & 0.97 \\
\hline & Min & 17 & 7 & 28 & 0.18 & 2.2 & 0.15 \\
\hline & \multirow[t]{3}{*}{ Max } & 58 & 52 & 110 & 2.5 & 19 & 1.9 \\
\hline & & $\mathrm{PM}_{2.5}$ & \multicolumn{2}{|r|}{$\mathrm{EC}$} & $\mathrm{OC}$ & \multicolumn{2}{|r|}{ Levoglucosan } \\
\hline & & $\mu \mathrm{g} \mathrm{m}^{-3}$ & \multicolumn{2}{|r|}{$\mu \mathrm{gC} \mathrm{m}{ }^{-3}$} & $\mu \mathrm{gC} \mathrm{m}^{-3}$ & \multicolumn{2}{|r|}{$\mu \mathrm{g} \mathrm{m}^{-3}$} \\
\hline \multirow{7}{*}{$8 \mathrm{~h}$} & Mean & 22 & \multicolumn{2}{|r|}{1.4} & 8.7 & \multicolumn{2}{|r|}{0.73} \\
\hline & Median & 16 & \multicolumn{2}{|r|}{1.0} & 6.2 & \multicolumn{2}{|r|}{0.42} \\
\hline & SD & 17 & \multicolumn{2}{|r|}{1.2} & 6.9 & \multicolumn{2}{|r|}{0.78} \\
\hline & $25^{\text {th }}$ Percentile & 9.5 & \multicolumn{2}{|r|}{0.54} & 3.5 & \multicolumn{2}{|r|}{0.195} \\
\hline & $75^{\text {th }}$ Percentile & 29 & \multicolumn{2}{|r|}{1.8} & 11 & \multicolumn{2}{|r|}{1.0} \\
\hline & Min & 2.2 & \multicolumn{2}{|r|}{0.090} & 0.90 & \multicolumn{2}{|r|}{0.053} \\
\hline & Max & 84 & \multicolumn{2}{|r|}{4.9} & 33 & \multicolumn{2}{|r|}{4.1} \\
\hline
\end{tabular}

Table 1. Main statistical parameters values calculated for 24-h time resolution $\left(\mathrm{PM}_{10}, \mathrm{PM}_{2.5}, \mathrm{OC}\right.$, EC, levoglucosan) and 8-h time resolution $\left(\mathrm{PM}_{2.5}, \mathrm{OC}, \mathrm{EC}\right.$, levoglucosan) concentrations. 
Levoglucosan was detected in all the collected samples, confirming the presence of woody biomass combustion as PM emission source in the sampling site. Daily levoglucosan concentrations vary from a minimum value of $0.15 \mu \mathrm{g} \mathrm{m}^{-3}$ on 18 February to a maximum value of $1.9 \mu \mathrm{g} \mathrm{m}^{-3}$ on 30 January, with a mean value of $0.75 \mu \mathrm{g} \mathrm{m}^{-3}$.

At higher time resolution $(8 \mathrm{~h}), \mathrm{PM}_{2.5}$ concentrations vary from $2 \mu \mathrm{g} \mathrm{m}^{-3}$ to $84 \mu \mathrm{g} \mathrm{m}^{-3}$ and levoglucosan from $0.053 \mu \mathrm{g} \mathrm{m}^{-3}$ to $4.1 \mu \mathrm{g} \mathrm{m}^{-3}$. As expected ACSM's m/z 60 and levoglucosan time series showed a good agreement, both showing temporal patterns similar to that of $\mathrm{PM}_{2.5}$ with higher concentrations from 4:00 p.m. to 8:00 a.m. (Fig. 3). More likely these high values are due to househeating/cooking activities. A similar trend observed for the EC/OC data support this hypothesis. This daily cycle of biomass burning indicators suggests the presence of significant local source rather than long-range transport. Generally, the major emission sources of fine OC and EC at urban-suburban areas are traffic, domestic heating, cooking and industrial activities (Piazzalunga et al., 2011). The high correlation coefficients between the woody biomass combustion tracers (levoglucosan and $\mathrm{m} / \mathrm{z}$ 60) and $\mathrm{PM}_{2.5}$ and EC/OC (Table 2) suggest that the biomass burning (domestic heating and cooking activities) is one of the most relevant sources of fine PM at the sampling site (Tzompa-Sosa et al., 2016).

\section{Estimations of BB Contribution to PM 10}

\section{PMF and Source Apportionment}

PMF analysis identified 9 factors (sources): fresh marine aerosol, soil dust, biomass combustion (BB), vehicular traffic emission, industrial/port activity, re-suspended dust, nitrate-rich secondary aerosol, sulfate-rich secondary aerosol and aged marine aerosol. In this section, the data for the biomass combustion source are shown and discussed; the other sources are reported in Supplementary Material (Fig. S2).

$\mathrm{BB}$ factor (Fig. 4) is well isolated, since it shows a profile characterized almost exclusively by $\mathrm{K}^{+}$, typically used as indicator of biomass burning in European source apportionment studies (Rodriguez et al., 2004; Andersen et al., 2007; Petralia et al., 2017), together with OC and EC with a relative contribution of $48.9 \%, 41.6 \%$ and $40.4 \%$, respectively. Furthermore, the EC/OC ratio (equal to 0.12 ) is in accordance with data previously reported on emissions from residential BB by Szidat et al. (2006); it is noteworthy the elevated correlation $(r=0.85)$ between 24-h levoglucosan and 24-h OC apportioned to BB by PMF.

Fig. 5 reports the mass contribution to $\mathrm{PM}_{10}\left(\mu \mathrm{g} \mathrm{m}^{-3}\right)$ for $\Sigma$ spec and for $\mathrm{PM}_{10}$ comp related to each factor. Fig. 6 shows the daily sources apportionment derived from the sum of all the speciated elements $(\Sigma$ spec $)$ and for parameter $\mathrm{PM}_{10 \text { comp }}$; for a more immediate interpretation, similar sources have been clustered: secondary inorganic aerosol, sea salt and soil dust come from clustering respectively nitrate-rich secondary aerosol and sulfate-rich secondary aerosol, fresh marine aerosol and aged marine aerosol, and soil dust and re-suspended dust.

$\Sigma$ spec is not sufficient to reconstruct the daily gravimetric $\mathrm{PM}_{10}$ mass concentration (Fig. 6(a)), while if $\mathrm{PM}_{10 \text { comp }}$ is considered in the PMF (Fig. 6(b)), the agreement between source reconstructed mass concentration and measured daily gravimetric $\mathrm{PM}_{10}$ mass concentration increases (Table 3). In particular, in Table 4 the single source contributions to $\mathrm{PM}_{10}$ are reported for the clustered sites. Even though the sources mass contribution to $\mathrm{PM}_{10}$ may differ among the two mass reconstructions (for BB $\Sigma$ spec is $5.0 \mu \mathrm{g} \mathrm{m}^{-3}$ while considering $\mathrm{PM}_{10}$ comp apportioned mass is $7.8 \mu \mathrm{g} \mathrm{m}^{-3}$ ), the

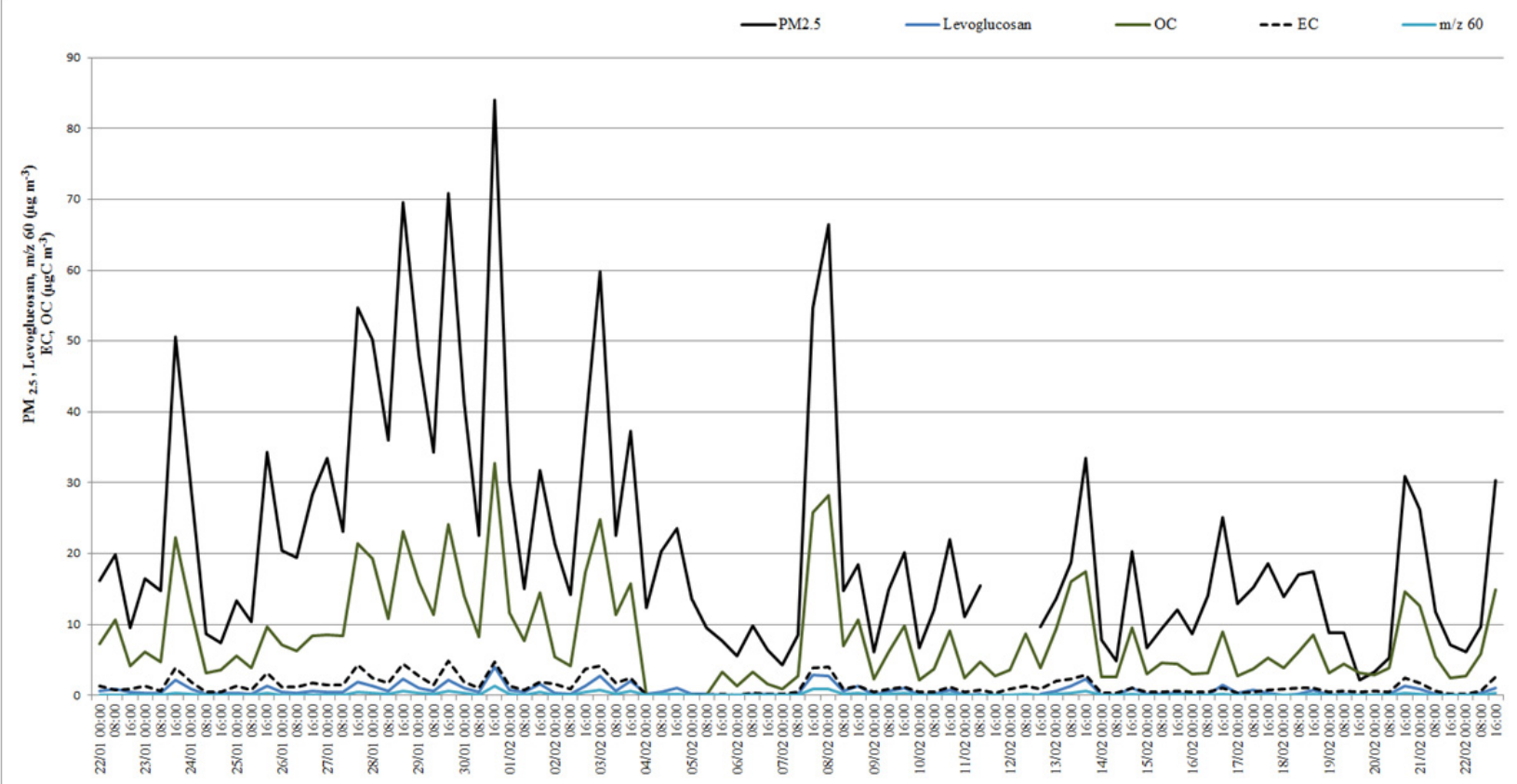

Fig. 3. 8-h concentration of $\mathrm{PM}_{2.5}$, levoglucosan, EC, OC, and m/z 60 during field campaign. 
Table 2. Levoglucosan, $\mathrm{EC}, \mathrm{OC}$, and $\mathrm{PM}_{1} \mathrm{BB}$ tracers $(\mathrm{m} / \mathrm{z} 60)$ linear correlation coefficients.

\begin{tabular}{lllll}
\hline & EC & OC & Levoglucosan & $\mathrm{m} / \mathrm{z} 60$ \\
\hline $\mathrm{PM}_{2.5}$ & 0.92 & 0.93 & 0.90 & 0.88 \\
$\mathrm{EC}$ & & 0.95 & 0.88 & 0.85 \\
OC & & & 0.93 & 0.92 \\
Levoglucosan & & & & 0.97 \\
\hline
\end{tabular}

relative contribution (Table S3) does not vary significantly (for BB the relative contribution is $20.2 \%$ and $20.3 \%$ for $\Sigma$ spec and $\mathrm{PM}_{10}$ comp, respectively).

The comparison of sources mass concentration obtained with $\Sigma$ spec and $\mathrm{PM}_{10}$ comp shows remarkable difference for specific sources and in particular for $\mathrm{BB}$, for which the difference is of $40 \%$. This discrepancy is related almost completely to the difference between OM and OC, since the organic fraction enters in PMF analysis as OC. To support this conclusion, we compared the BB OC-to-OM conversion factor, $f_{B B}$ equal to 1.86 , reported in Genga et al. (2017) and Philip et al. (2014), with the one calculated here $\left(f_{B B_{P} P M F}\right)$ :

$f_{B B_{-} P M \mathrm{~F}}=\left[O C_{B B}+\left(\mathrm{PM}_{10 \_ \text {comp }}-\mathrm{PM}_{10 \Sigma \text { spec }}\right)\right] / O C_{B B}$ where $O C_{B B}$ is the $\mathrm{OC}$ apportioned by PMF to biomass burning factor. The obtained $f_{B B_{-} P M F}$ value (equal to 1.70 ) is in good agreement with the literature value, therefore supporting our conclusion that the difference between $\mathrm{PM}_{10}$ comp and $\Sigma$ spec is related to the uncertainties in the quantification of OM starting from $\mathrm{OC}$ data.

As reported in "Biomass Burning Identification Methods: Positive Matrix Factorization (PMF) and Macro Tracer

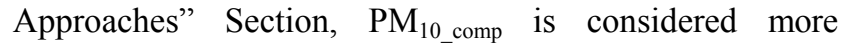
representative of gravimetric measured $\mathrm{PM}_{10}$ (Fig. S3) since it reproduces almost completely the $\mathrm{PM}_{10}$ mass, associated to all the sources; for clearness and for comparison with the macro tracer approach from now on we will refer just to $\mathrm{BB}$ obtained from $\mathrm{PM}_{10}$ comp $\mathrm{PMF}\left(\mathrm{BB}_{\mathrm{PMF}}\right)$.

\section{BB Macro Tracer Approach}

In order to calculate the $\mathrm{BB}_{\text {Levo }}$ contribution to $\mathrm{PM}_{10}, 8-\mathrm{h}$ levoglucosan concentrations were averaged every $24 \mathrm{~h}$ and multiplied for the conversion factors $\left(\mathrm{F}_{\mathrm{W} 1}, \mathrm{~F}_{\mathrm{W} 2}\right.$, and $\left.\mathrm{F}_{\mathrm{W} 3}\right)$ calculated, as reported in "Biomass Burning Identification Methods: Positive Matrix Factorization (PMF) and Macro Tracer Approaches" Section.

Although $\mathrm{PM}_{10}$ and $\mathrm{BB}_{\text {Levo }}$ contributions show the same

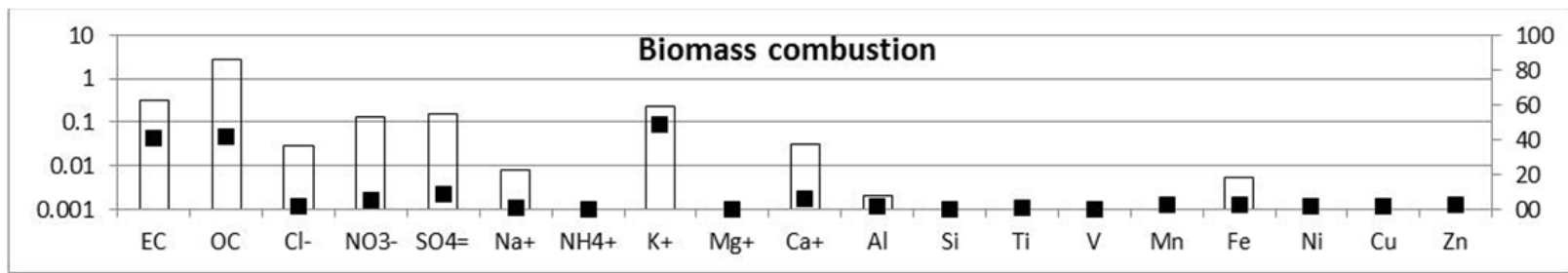

Fig. 4. Biomass burning factor profile obtained from PMF analysis; vertical bars (principal $y$-axis): mass concentration $\left(\mu \mathrm{g} \mathrm{m}^{-3}\right)$ of the single element in the factor; black squares (secondary $y$-axis): \% contribution of the single element in the factor over the totality of factors.

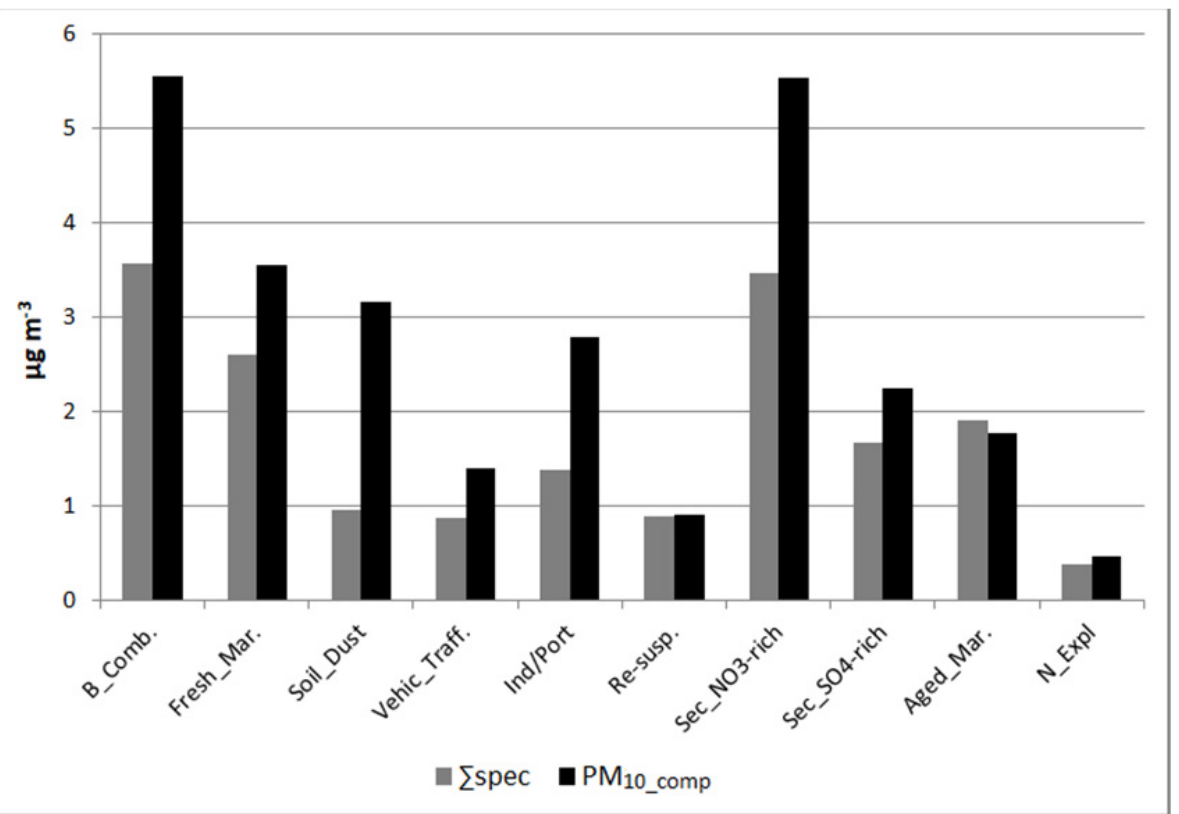

Fig. 5. Mass contribution $\left(\mu \mathrm{g} \mathrm{m}^{-3}\right)$ of factors to $\Sigma$ spec (grey bars) and mass contribution $\left(\mu \mathrm{g} \mathrm{m}^{-3}\right)$ of $\mathrm{PM}_{10}$ comp (black bars) attributable to each factor. N_Expl: unexplained mass. 

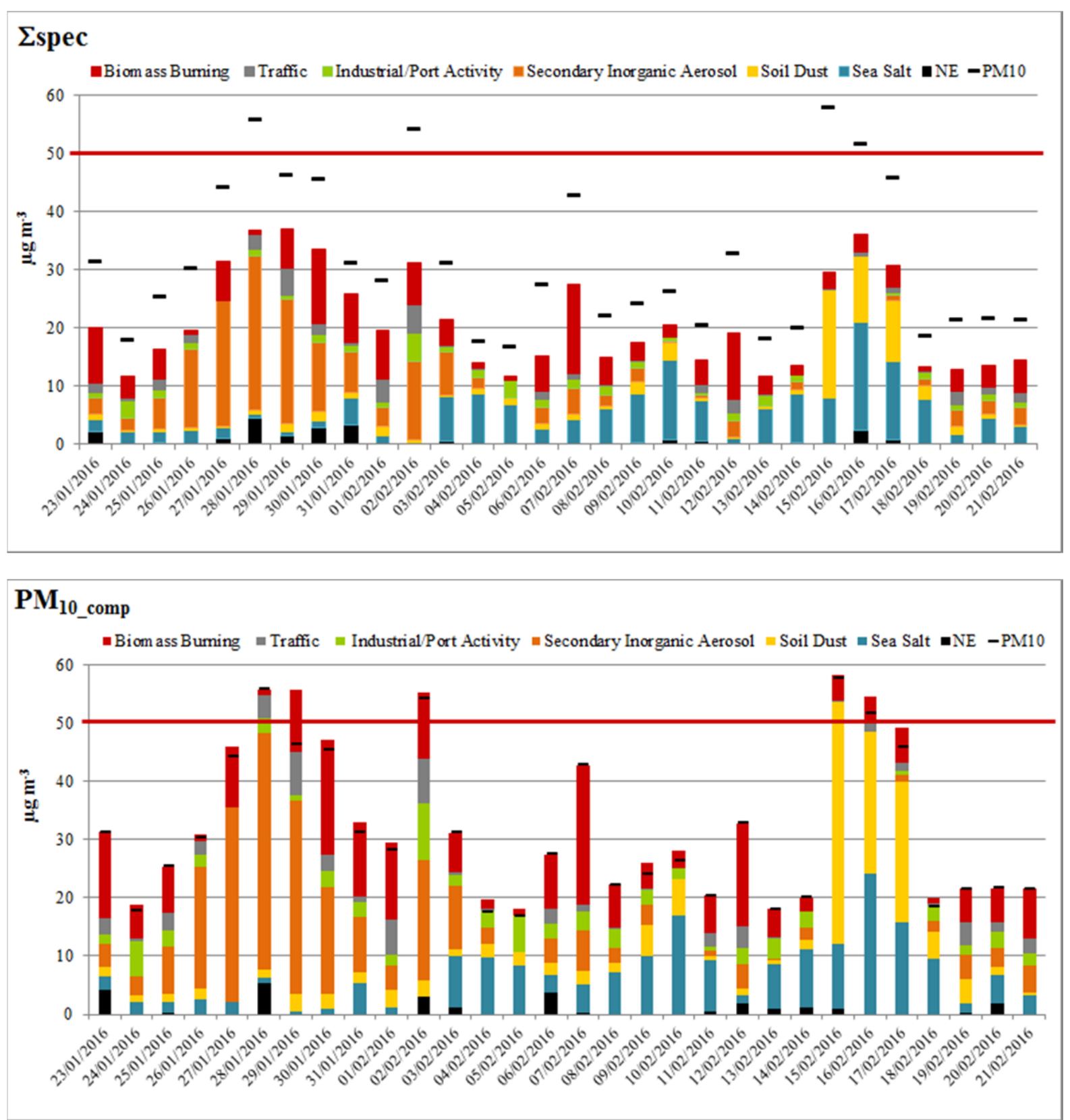

Fig. 6. Daily sources apportionment derived from the sum of all the speciated elements, (a) $\Sigma$ spec and (b) for parameter $\mathrm{PM}_{10 \_ \text {comp. }}$ Secondary inorganic aerosol, sea salt and soil dust come from clustering respectively nitrate-rich secondary aerosol and sulfate-rich secondary aerosol, fresh marine aerosol and aged marine aerosol, soil dust and re-suspended dust.

Table 3. Mean, median, standard deviation, minimum and maximum values for $\mathrm{PM}_{10}$ and $\Sigma$ spec and $\mathrm{PM}_{10 \text { comp }}$ mass reconstruction.

\begin{tabular}{llll}
\hline & $\mathrm{PM}_{10}$ & $\Sigma$ spec & $\mathrm{PM}_{10 \text { comp }}$ \\
\cline { 2 - 4 } & $\mu \mathrm{g} \mathrm{m}^{-3}$ & $\mu \mathrm{g} \mathrm{m}^{-3}$ & $\mu \mathrm{g} \mathrm{m}^{-3}$ \\
\hline Mean & 32 & 21 & 32 \\
Median & 28 & 19 & 28 \\
SD & 13 & 8 & 13 \\
$25^{\text {th }}$ Percentile & 21 & 14 & 20 \\
$75^{\text {th }}$ Percentile & 45 & 29 & 45 \\
Min & 17 & 12 & 17 \\
Max & 58 & 37.0 & 57 \\
\hline
\end{tabular}

trend, their maximum and minimum concentration values differ in occurring days. The highest $\mathrm{BB}_{\text {Levo }}$ mass concentration value was recorded on 30 January, with 15 , 21 and $36 \mu \mathrm{g} \mathrm{m}^{-3}$ depending on the specific $F_{W}$ considered while the lowest occurred on 18 February, with 1.2, 1.7, and $2.9 \mu \mathrm{g} \mathrm{m}^{-3}$. The relative $\mathrm{BB}_{\text {Levo }}$ contribution to $\mathrm{PM}_{10}$ shows maximum value on 12 February $(35,49$, and $84 \%$ ) and minimum on 18 February $(6,8$, and $14 \%$ ) (Table 5).

The $\mathrm{BB}_{\mathrm{Levo}}$ daily contribution to $\mathrm{PM}_{10}$ estimated with macro tracer method ranges from 18 to $44 \%$, depending on the specific $F_{W}$ value (Table 5) and on the conversion factor used in Eq. (1). In order to evaluate the $F_{W}$ more representative of the specific conditions of the studied area 


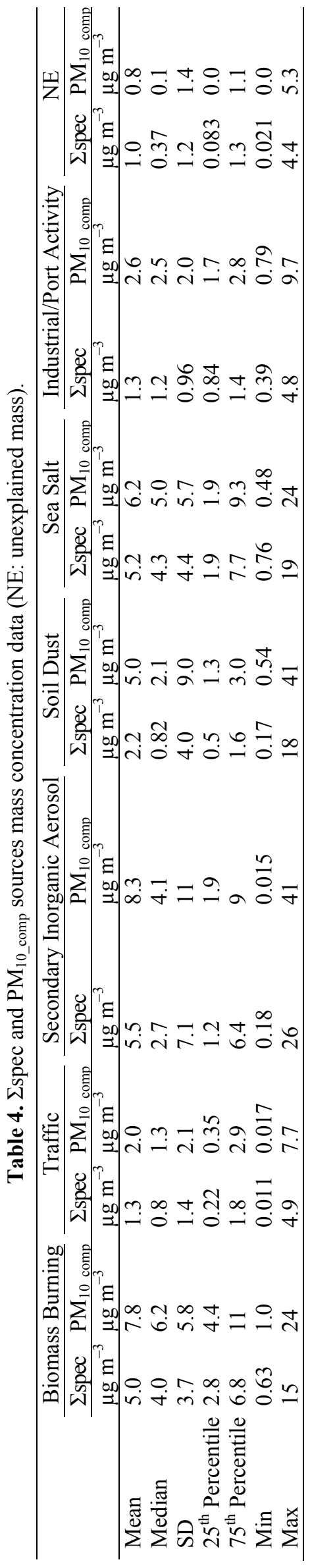

Table 5. Relative BB contribution to $\mathrm{PM}_{10}$ calculated by means of $F_{W 1}, F_{W 2}$ and $F_{W 3}$.

\begin{tabular}{llll}
\hline & $\mathrm{BB} \% \mathrm{PM}_{10}$ & $\mathrm{BB} \% \mathrm{PM}_{10}$ & $\mathrm{BB} \% \mathrm{PM}_{10}$ \\
\cline { 2 - 4 } & $\mathrm{F}_{\mathrm{W} 1}$ & $\mathrm{~F}_{\mathrm{W} 2}$ & $\mathrm{~F}_{\mathrm{W} 3}$ \\
\hline Mean & 18 & 44 & 26 \\
Median & 18 & 43 & 25 \\
SD & 8 & 20 & 12 \\
$25^{\text {th }}$ Percentile & 11 & 27 & 16 \\
$75^{\text {th }}$ Percentile & 23 & 55 & 32 \\
Min & 6 & 14 & 8 \\
Max & 35 & 84 & 49 \\
\hline
\end{tabular}

the comparison of the independent results from PMF and macro tracer has been performed as reported in the following section.

\section{Comparison between Macro Tracer Method and PMF Method}

Since levoglucosan concentrations are available just for TF site, only the data from this site were extracted from the PMF output dataset and compared with the macro tracer results. $\mathrm{BB}$ contribution to $\mathrm{PM}_{10}$ calculated by means of the two independent methods $\left(\mathrm{BB}_{\mathrm{PMF}}\right.$ and $\left.\mathrm{BB}_{\mathrm{Levo}}\right)$ were analyzed by linear correlation. $\mathrm{BB}_{\text {Levo }}$ calculated with $F_{W 3}$ best fitted the $\mathrm{BB}_{\mathrm{PMF}}$ values with $r$ value equal to 0.85 and a slope value equal to 0.9 (Fig. 7): The slope value close to 1 indicates a tight correspondence between the data series obtained with the two independent methods. $\mathrm{BB}_{\mathrm{PMF}}$ varies from $1.0 \mu \mathrm{g} \mathrm{m}^{-3}$ to $24 \mu \mathrm{g} \mathrm{m}^{-3}$ with a mean value of $7.8 \mu \mathrm{g} \mathrm{m}^{-3}$, while $\mathrm{BB}_{\text {Levo }}$, calculated with $F_{W 3}$, from $1.7 \mu \mathrm{g} \mathrm{m}^{-3}$ to $21 \mu \mathrm{g} \mathrm{m}^{-3}$ with a mean value of $8.5 \mu \mathrm{g} \mathrm{m}^{-3}$. The relative contribution to gravimetric $\mathrm{PM}_{10}$ is $25 \%$ and $26 \%$ for $\mathrm{BB}_{\mathrm{PMF}}$ and $\mathrm{BB}_{\text {Levo }}$ respectively.

$\mathrm{BB}$ is the main source of PM in the studied area, accounting for about $30 \%$ (range from a minimum of $10 \%$ to a maximum of 50\%). Nava et al. (2015) reported a comparable value of $\mathrm{BB}$ contribution to $\mathrm{PM}_{10}(37 \%)$ for a Centre of Italy site, confirming the relevant contribution of BB in suburban areas of Italy.

Even though levoglucosan may undergo atmospheric degradation processes, in our case we can speculate a relative chemical stability considering the agreement with the calculated daily BB mass contribution by the two methods.

As already explained in Section "Biomass Burning Identification Methods: Positive Matrix Factorization (PMF) and Macro Tracer Approaches", the $F_{W 3}$ assumes an olive emission coefficient intermediate between oak and beech ones. Since in the studied area olive is the most burned wood species (about 70\%; Spagnolo et al., 2014) we tried to determine a hypothetical olive emission factor $x$ from the data of the daily $\mathrm{BB}_{\mathrm{PMF}}$ contributions:

$x=\left\{100-\left[\left(F_{W_{-} P M F} \times 0.05\right.\right.\right.$ Beech $\left.\times 4.1\right)+\left(F_{W_{-} P M F} \times 0.05\right.$ Oak $\times 13.3)+\left(\bar{F}_{W_{-} P M F} \times 0.1 \times\right.$ Pellet $\left.\left.\left.\times 10.1\right)\right]\right\} /\left(F_{W_{-} P M F} \times\right.$ $0.8)$

where

$\left.F_{W_{-} P M F}=B B_{P M F}\left(\mu \mathrm{g} \mathrm{m}^{-3}\right)\right)[$ Levoglucosan $]\left(\mu \mathrm{g} \mathrm{m}^{-3}\right)$. 


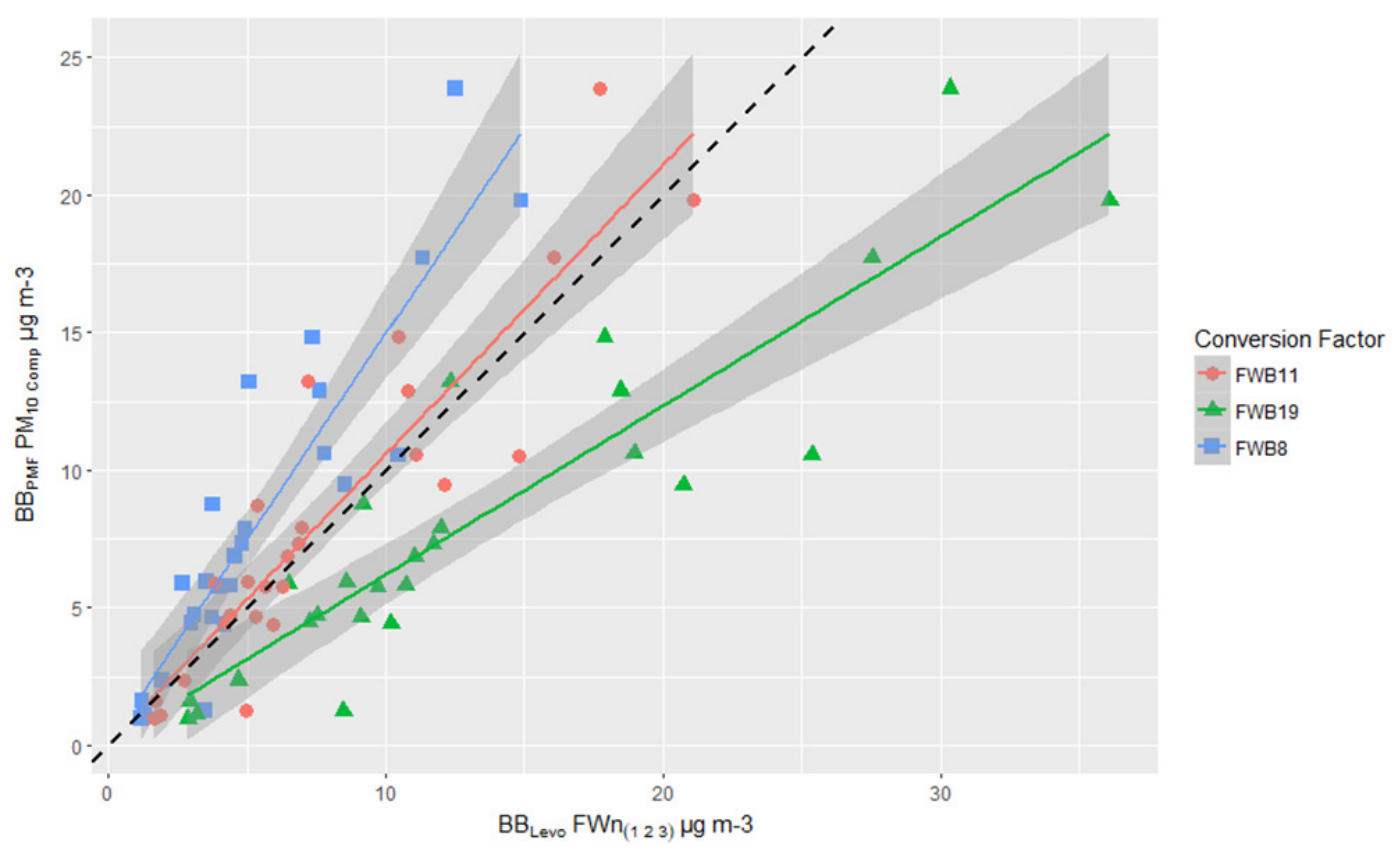

Fig. 7. $\mathrm{BB}_{\mathrm{PMF}}$ and $\mathrm{BB}_{\text {Levo }} F_{W}(11,19,8)$ linear correlation.

Calculated olive emission factor results on average equal to 12 . This value, derived from mathematical calculations and theoretical approximations, should be confirmed by further experimental emission tests on olive wood but represents to our knowledge the first proposed conversion factor for this wood species. Interestingly Fourtziou et al. (2017) reported a relation factor between levoglucosan and night $\mathrm{PM}_{1}$ equal to 11.25 as representative for samplings in Greece where olive wood biomass is used for domestic heating. However, Maenhaut et al. (2016) reported a conversion factor for Flanders region equal to 22.6. This value is higher than the values here considered representative for olive biomass burning but is in line with other conversion factors reported for other northern Europe regions: In Finland, Saarnio et al. (2012) reported a factor equal to 24, equal to median value reported in Switzerland (Gianini et al., 2013). Higher conversion factors have been also reported, for example by Ducret-Stich et al. (2013) for a Swiss Alpine valley (factor equal to 37 ).

\section{CONCLUSIONS}

Gravimetric measurements and detailed chemical characterizations of PM were performed in the study area to identify the main emission sources, with particular attention to $\mathrm{BB}$. The daily values for $\mathrm{PM}_{10}$ varied between $9 \mu \mathrm{g} \mathrm{m}^{-3}$ and $51 \mu \mathrm{g} \mathrm{m}^{-3}$, with the fine fraction representing, on average, about $70 \%$ of the concentration.

PMF was shown to be a good method for quantifying the emission sources, although the difference between the sum of the reconstructed speciation parameters $(\Sigma$ spec $)$ and the experimentally measured gravimetric $\mathrm{PM}_{10}$ remains an issue to be solved. On the other side, the macro tracer approach, developed and applied mostly in the Alpine region, easily facilitated the evaluation of $\mathrm{BB}$, although the available conversion factors $\left(F_{W}\right)$ do not cover the entire variety of woody biomass burned in Europe.

These two methods (PMF and the macro tracer approach) showed good agreement, as confirmed by the correlation coefficient $(\mathrm{r}=0.85)$ and the slope (close to 1$)$. The values for the mean concentration as well as the minimum and maximum values from the 24-h $\mathrm{BB}_{\mathrm{PMF}}$ and $\mathrm{BB}_{\text {Levo }}$ series were, in fact, comparable: $7.8 \mathrm{vs} .8 .5 \mu \mathrm{g} \mathrm{m}^{-3}$ for the average, 1.0 vs. $1.7 \mu \mathrm{g} \mathrm{m}^{-3}$ for the minimum and $24 \mathrm{vs} .21 \mu \mathrm{g} \mathrm{m}^{-3}$ for the maximum. BB was identified as one of the most significant sources of $\mathrm{PM}_{10}$ in the study area, contributing, on average, slightly less than $30 \%$, with a maximum of $50 \%$ and a minimum of $10 \%$.

Comparing the results from these two independent methods also allowed us to determine a possible conversion factor that is specific to the studied area and potentially representative of olive wood burning. Furthermore, the good agreement between the methods led us to identify and exclude an underestimation of the $\mathrm{BB}$ contribution in the macro tracer approach due to levoglucosan degradation. Levoglucosan is thus confirmed as a valid tracer for BB during winter in the examined area, exhibiting a dailycycle (over $8 \mathrm{~h}$ ) that corresponds to the expected househeating/cooking activities, with higher concentrations during the late afternoon and night.

Integrating these two methods therefore results in a good methodology for realistically and independently quantifying BB's contribution to PM. Applying this approach to other case studies may further confirm the utility of this dual evaluation and of identifying specific conversion factors $\left(F_{w}\right)$. These conversion factors, mathematically identified and demonstrated with ad hoc tests, can also be used in simple and cheap procedures to routinely evaluate BB in the long term, increasing our knowledge of BB's impact on air quality in every region of Europe. Furthermore, establishing a 
database of $F_{w}$ values that are representative of different geographical areas may enable the development of automated instruments for the real time quantification of BB.

The two methods, each with its specific strengths and weaknesses, converge when evaluating BB in the studied area. We recommend that this integrated approach be considered a state of the art procedure for the quantification of BB.

\section{ACKNOWLEDGMENTS}

This work was supported by ENEL s.p.a. The authors wish to thank Dr. Carmela Tortorella, Dr. Silvana Iacobellis, Dr. Aldo Giove, Mr. Renato Nacci and Dr. Daniele Marseglia for the precious support throughout the study.

\section{SUPPLEMENTARY MATERIAL}

Supplementary data associated with this article can be found in the online version at http://www.aaqr.org.

\section{REFERENCES}

Alfarra, M.R., Prévôt, A.S.H., Szidat, S., Sandradewi, J., Weimer, S., Lanz, V.A., Schreiber, D., Mohr, M. and Baltensperger, U. (2007). Identification of the mass spectral signature of organic aerosols from wood burning emissions. Environ. Sci. Technol. 41: 57705777.

Andersen, Z.J., Wahlin, P., Raaschou-Nielsen, O., Scheike, T. and Loft, S. (2007). Ambient particle source apportionment and daily hospital admissions among children and elderly in Copenhagen. J. Exposure Sci. Environ. Epidemiol. 17: 625-636.

Bae, M.S., Demerjian, K.L. and Schwab, J.J. (2006). Seasonal estimation of organic mass to organic carbon in $\mathrm{PM}_{2.5}$ at rural and urban locations in New York state. Atmos. Environ. 40: 7467-7479.

Belis, C.A., Larsen, B.R., Amato, F., El Haddad, I., Favez, O., Harrison, R.M., Hopke, P.K., Nava, S., Paatero, P., Prévôt, A.S.H., Quass, U., Vecchi, R. and Viana, M. (2014). European guide on air pollution source apportionment with receptor models. European Commission - Joint Research Centre Institute for Environment and Sustainability.

Belis, C.A., Pernigotti, D., Karagulian, F., Pirovano, G., Larsen, B.R., Gerboles, M. and Hopke, P.K. (2015a). A new methodology to assess the performance and uncertainty of source apportionment models in intercomparison exercises. Atmos. Environ. 119: 35-44.

Belis, C.A., Karagulian, F., Amato, F., Almeida, M., Artaxo, P., Beddows, D.C.S., Bernardoni, V., Bove, M.C., Carbone, S., Cesari, D., Contini, D., Cuccia, E., Diapouli, E., Eleftheriadis, K., Favez, O., El Haddad, I., Harrison, R.M., Hellebust, S., Hovorka, J., Jang, E., Jorquera, H., Kammermeier, T., Karl, M., Lucarelli, F., Mooibroek, D., Nava, S., Nøjgaard, J.K., Paatero, P., Pandolfi, M., Perrone, M.G., Petit, J.E., Pietrodangelo, A., Pokorn, P., Prati, P., Prevot, A.S.H., Quass, U.,
Querol, X., Saraga, D., Sciare, J., Sfetsos, A., Valli, G., Vecchi, R., Vestenius, M., Yubero, E. and Hopke, P.K. (2015b). A new methodology to assess the performance and uncertainty of source apportionment models II: The results of two European intercomparison exercises. Atmos. Environ. 123: 240-250.

Bernardoni, V., Vecchi, R., Valli, G., Piazzalunga, A. and Fermo, P. (2011). $\mathrm{PM}_{10}$ source apportionment in Milan (Italy) using time-resolved data. Sci. Total Environ. 409: 4788-4795.

Busby, B.D., Ward, T.J., Turner, J.R. and Palmer, C.P. (2016). Comparison and evaluation of methods to apportion ambient $\mathrm{PM}_{2.5}$ to residential wood heating in Fairbanks, AK. Aerosol Air Qual. Res. 16: 492-503.

Ducret-Stich, R.E., Tsai, M.Y., Thimmaiah, D., Künzli, N., Hopke, P.K. and Phuleria, H.C. (2013). $\mathrm{PM}_{10}$ source apportionment in a Swiss Alpine valley impacted by highway traffic. Environ. Sci. Pollut. Res. 20: 64966508.

European Commission Staff Working Document, Impact Assessment, Accompanying the document Communication from the Commission to the European Parliament, the Council, the European Economic and Social Committee and the Committee of the Regions; A policy framework for climate and energy in the period from 2020 up to 2030. SWD(2014).

European Commission, Report from the Commission to the European Parliament, the Council, the European economic and social Committee and the Committee of the Regions; Renewable energy progress report, SWD(2015) 117 Final.

European Commission, Council Directive 2004/107/CE of 15 December 2004 of the European Parliament and of the Council relating to arsenic, cadmium, mercury, nickel and polycyclic aromatic hydrocarbons in ambient air. Official Journal of the European Union, 26.1.2005, En series, L 23/3.

European Commission, Council Directive 2008/50/EC of 21 May 2008 of the European Parliament and of the Council on Ambient air quality and cleaner air for Europe. Official Journal of the European Union, 11.6.2008, En series, L152/1.

Fine, P.M., Cass, G.R. and Simoneit, B.R.T. (2002). Chemical characterization of fine particle emissions from the fireplace combustion of woods grown in the Southern United States. Environ. Sci. Technol. 36: 1442-1451.

Fourtziou, L., Liakakou, E., Stavroulas, I., Theodosi, C., Zarmpas, P., Psiloglou, B. and Mihalopoulos, N. (2017). Multi-tracer approach to characterize domestic wood burning in Athens (Greece) during wintertime. Atmos. Environ. 148: 89-101.

Gelencsér, A., May, B., Simpson, D., Sánchez-Ochoa, A., Kasper-Giebl, A., Puxbaum, H., Caseiro, A., Pio, C. and Legrand, M. (2007). Source apportionment of $\mathrm{PM}_{2.5}$ organic aerosol over Europe: Primary/secondary, natural/anthropogenic, and fossil/biogenic origin. $J$. Geophys. Res. 112: D23S04.

Genga, A., Ielpo, P., Siciliano, T. and Siciliano, M. (2017). 
Carbonaceous particles and aerosol mass closure in $\mathrm{PM}_{2.5}$ collected in a port city. Atmos. Res. 183: 245-254.

Gianini, M.F.D., Piot, C., Herich, H., Besombes, J.L., Jaffrezo, J.L. and Hueglin, C. (2013). Source apportionment of $\mathrm{PM}_{10}$, organic carbon and elemental carbon at Swiss sites: An intercomparison of different approaches. Sci. Total Environ. 454-455: 99-108.

Hennigan, C.J., Sullivan, A.P., Collett, Jr. J.L. and Robinson, A.L. (2010). Levoglucosan stability in biomass burning particles exposed to hydroxyl radicals. Geophys. Res. Lett. 37: L09806.

Hoffmann, D., Tilgner, A., Iinuma, Y. and Herrmann, H. (2010). Atmospheric stability of levoglucosan: A detailed laboratory and modeling study. Environ. Sci. Technol. 44: 694-699.

Iinuma, Y., Engling, G., Puxbaum, H. and Herrmann, H. (2009). A highly resolved anion-exchange chromatographic method for determination of saccharidic tracers for biomass combustion and primary bio-particles in atmospheric aerosol. Atmos. Environ. 43: 1367-1371.

Karagulian, F., Belis, C.A. and Borowiak, A. (2012). Results of the European intercomparison exercise for receptor models 2011-2012. Part I. European Commission. Joint Research Centre Institute for Environment and Sustainability.

Kistler, M., Schmidl, C., Padouvas, E., Giebla, H., Lohninger, J., Ellinger, R., Bauer, H. and Puxbaum H. (2012). Odor, gaseous and $\mathrm{PM}_{10}$ emissions from small scale combustion of wood types indigenous to Central Europe. Atmos. Environ. 51: 86-93.

Kocak, M., Theodosi, C., Zampas, P., Séguret, M.J.M., Herut, B., Kallos, G., Mihalopoulos, N., Kubilay, N. and Nimmo, M. (2012). Influence of mineral dust transport on the chemical composition and physical properies of the Eastern Mediterranean aerosol. Atmos. Environ. 57: 266-277.

Lai, C., Liu, Y., Ma, J., Ma, Q. and He, H. (2014). Degradation kinetics of levoglucosan initiated by hydroxyl radical under different environmental conditions. Atmos. Environ. 91: 32-39.

Malaguti, A., Mircea, M., La Torretta, T. M. G., Telloli, C., Petralia, E., Stracquadanio, M. and Berico, M. (2015a). Chemical composition of fine and coarse aerosol particles in the Central Mediterranean area during dust and non-dust conditions. Aerosol Air Qual. Res. 15: 410-425.

Malaguti, A., Mircea, M., La Torretta, T.M.G., Telloli, C., Petralia, E., Stracquadanio, M. and Berico, M. (2015b). Comparison of online and offline methods for measuring fine secondary inorganic ions and carbonaceous aerosols in the central Mediterranean area. Aerosol Air Qual. Res. 15: 2641-2653.

Maenhaut, W., Vermeylen, R., Claeys, M., Vercauteren, J., and Roekens, E. (2016). Sources of the $\mathrm{PM}_{10}$ aerosol in Flanders, Belgium, and re-assessment of the contribution from wood burning. Sci. Total Environ. 562: 550-560.

Nava, S., Lucarelli, F., Amato, F., Becagli, S., Calzolai, G., Chiari, M. and Udisti, R. (2015). Biomass burning contributions estimated by synergistic coupling of daily and hourly aerosol composition records. Sci. Total Environ. 511: 11-20.

Nielsen, I.E., Eriksson, A.C., Lindgren, R., Martinsson, J., Nyström, R., Nordin, E.Z., Sadiktsis, I., Boman, C., Nøjgaard, J.K. and Pagels, J. (2017). Time-resolved analysis of particle emissions from residential biomass combustion - Emissions of refractory black carbon, PAHs and organic tracers. Atmos. Environ. 165: 179-190.

Norris, G., Duvall, R., Brown, S. and Bai, S. (2014). EPA Positive Matrix Factorization (PMF) 5.0 fundamentals and user guide. U.S. Environmental Protection Agency, Office of Research and Development, Washington, DC, USA.

Paatero, P. and Tapper, U. (1994). Positive Matrix Factorization: A non-negative factor model with optimal utilization of error estimates of data values. Environmetrics 5: 111-126.

Paatero, P. (2004). User's guide for positive matrix factorization programs PMF2 and PMF3, Part1: tutorial. University of Helsinki, Helsinki, Finland.

Pernigotti, D., Belis, C.A. and Spanò, L. (2016). SPECIEUROPE: The European data base for PM source profiles. Atmos. Pollut. Res. 7: 307-314 (on line database at http://source-apportionment.jrc.ec.euro pa.eu/Specieurope/index.aspx).

Perrino, C., Canepari, S. and Catrambone, M. (2013). Comparing the performance of teflon and quartz membrane filters collecting atmospheric PM: Influence of atmospheric water. Aerosol Air Qual. Res. 13: 137147.

Perrino, C., Catrambone, M., Dalla Torre, S., Rantica, E., Sargolini, T. and Canepari, S. (2014). Seasonal variations in the chemical composition of particulate matter: A case study in the Po Valley. Part I: Macro-components and mass closure. Environ. Sci. Pollut. Res. 21: 39994009.

Petralia, E., Berico, M., La Torretta, T., Malaguti, A., Stracquadanio, M. and Telloli, C. (2017). Identification of emission sources from data of $\mathrm{PM}_{2.5}$ chemical speciation measured with automatic monitors: application in a coastal site of the Mediterranean basin. Biodiversity J. 8: 59-64.

Philip, S., Martin, R.V., Pierce, J.R., Jimenez, J.L., Zhang, Q., Canagaratna, M.R., Spracklen, D.V., Nowlan, C.R., Lamsal, L.N., Cooper, M.J. and Krotkov, N.A. (2014). Spatially and seasonally resolved estimate of the ratio of organic mass to organic carbon. Atmos. Environ. 87: 3440.

Piazzalunga, A., Belis, C., Bernardoni, V., Cazzuli, O., Fermo, P., Valli, G. and Vecchi, R. (2011). Estimates of wood burning contribution to PM by the macro-tracer method using tailored emission factors. Atmos. Environ. 45: 6642-6649.

Rodríguez, S., Querol, X., Alastuey, A., Viana, M.M., Alarcón, M., Mantilla, E. and Ruiz, C. (2004). Comparative $\mathrm{PM}_{10}-\mathrm{PM}_{2.5}$ source contribution study at rural, urban and industrial sites during PM episodes in Eastern Spain. Sci. Total Environ. 328: 95-113. 
Saarnio, K., Niemi, J.V., Saarikoski, S., Aurela, M., Timonen, H., Teinilä, K., Myllynen, M., Frey, A., Lamberg, H., Jokiniemi, J. and Hillamo, R. (2012). Using monosaccharide anhydrides to estimate the impact of wood combustion on fine particles in the Helsinki Metropolitan Area. Boreal Environ. Res. 17: 163-183.

Schmidl, C., Marr, I.L, A. Caseiro, A., Kotianová, P., Berner, A., Bauer, H., Kasper-Giebl, A. and Puxbaum, H. (2008). Chemical characterisation of fine particle emissions from wood stove combustion of common woods growing in mid-European Alpine regions. Atmos. Environ. 42: 126-141.

Sciare, J., Oikonomou, K., Cachier, H., Mihalopoulos, N., Andreae, M.O., Maenhaut, W. and Sarda-Estève R. (2005). Aerosol mass closure and reconstruction of the light scattering coefficient over the Eastern Mediterranean Sea during the MINOS campaign. Atmos. Chem. Phys. 5: 2253-2265.

Shahid, I., Kistler, M., Shahid, M.Z. and Puxbaum, H. (2019). Aerosol chemical characterization and contribution of biomass burning to particulate matter at a residential site in Islamabad, Pakistan. Aerosol Air Qual. Res. 19: 148-162.

Simoneit, B.R.T., Schauer, J.J., Nolte, C.G., Oros, D.R., Elias, V.O., Fraser, M.P., Rogge, W.F. and Cass, G.R. (1999). Levoglucosan, a tracer for cellulose in biomass burning and atmospheric particles. Atmos. Environ. 33: 173-182.

Spagnolo, S., Bevere, M., Giua, R., Pastore, T. and Valentini, E. (2014). Inventario delle emissioni di aerosol provenienti dalla combustione di biomasse in Puglia, Contribution ID:91, PM2014 Genova, Italy.

Szidat, S., Jenk, T.M., Synal, H.A., Kalberer, M., Wacker, L., Hajdas, I., Kasper-Giebl, A. and Baltensperger U. (2006). Contributions of fossil fuel, biomass-burning, and biogenic emissions to carbonaceous aerosols in Zurich as traced by ${ }^{14}$ C. J. Geophys. Res. 111: D07206.

Terzi, E., Argyropoulos, G., Bougatioti, A., Mihalopoulos, N., Nikolaou, K. and Samara, C. (2010). Chemical composition and mass closure of ambient $\mathrm{PM}_{10}$ at urban sites. Atmos. Environ. 44: 2231-2239.

Tzompa-Sosa, Z.A., Sullivan, A.P., Retama, A. and Kreidenweis S.M. (2016). Contribution of biomass burning to carbonaceous aerosols in Mexico City during May 2013. Aerosol Air Qual. Res. 16: 114-124.

Viana, M., Kuhlbusch, T.A.J., Querol, X., Alastuey, A., Harrison, R.M., Hopke, P.K., Winiwarter, W., Vallius, M., Szidat, S., Prévôt, A.S.H., Hueglin, C., Bloemen, H., Wåhlin, P., Vecchi, R., Miranda, A.I., Kasper-Giebl, A., Maenhaut, W. and Hitzenberger, R. (2008). Source apportionment of particulate matter in Europe: A review of methods and results. J. Aerosol Sci. 39: 827-849.

Waked, A., Favez, O., Alleman, L.Y., Piot, C., Petit, J.E., Delaunay, T., Verlinden, E., Golly, B., Besombes, J.L., Jaffrezo, J.L. and Leoz-Garziandia, E. (2014). Source apportionment of $\mathrm{PM}_{10}$ in a north-western Europe regional urban background site (Lens, France) using positive matrix factorization and including primary biogenic emissions. Atmos. Chem. Phys. 14: 3325-3346.

Yttri, K.E., Simpson, D., Nøjgaard, J.K., Kristensen, K., Genberg, J., Stenström, K., Swietlicki, E., Hillamo, R., Aurela, M., Bauer, H., Offenberg, J.H, Jaoui, M., Dye, C., Eckhardt, S., Burkhart, J.F., Stohl, A. and Glasius, M. (2011). Source apportionment of the summer time carbonaceous aerosol at Nordic rural background sites. Atmos. Chem. Phys. 11: 13339-13357.

Received for review, May 23, 2018 Revised, September 21, 2018 Accepted, November 12, 2018 